\title{
Landscape-indicator development: steps towards a European approach
}

\author{
D. M. Wascher ${ }^{\#}$
}

\begin{abstract}
The large diversity of landscapes characteristic for specific regions is one of the key cultural-heritage elements of Europe, although there is a tendency for regional differences to disappear. In view of the increasing interest in landscape-related concepts expressed by policy institutes such as the European Commission, the European Environment Agency (EEA), the Council of Europe and the OECD, national activities in the field of landscape indicators are becoming an important reference when developing European-wide assessments. Being strongly rooted in earth sciences (soil, water, land use, biodiversity) as well as social sciences, landscape indicators can play an essential role when assessing the sustainability of Europe's rural and peri-urban land. After reviewing recent international approaches to landscape-indicator development on the basis of a conceptual framework that integrates landscape functions in the context of DPSIR, this paper explores national approaches to 'Landscape Character Assessment' as references for the practical application of indicators. Finally, a set of conclusions and recommendations addressing scientists and policymakers are given.
\end{abstract}

Keywords: Landscape indicators; DPSIR; landscape character

\section{Introduction: conceptual framework}

Landscapes are based on natural features such as climate, relief, soil type and water availability as well as on human intervention through agriculture, transhumance, forestry, rural policies, economic pressures and other cultural influences. Hence, both natural and cultural features should be considered when defining landscape. Building upon a definition that has been developed at an international workshop (Landscape Europe 2001), it is proposed to use the following adaptation of the definition of landscape: "Landscapes are spatially defined units, whose character and functions are defined by the complex and region-specific interaction of natural processes with human activities that are driven by economic, social and environmental forces and values."

Like many other landscape definitions that have been developed during the last decades, the above approach is meant to fit a specific purpose - in this case the research objectives for landscape assessment at the international level. Inspired by Wagner and Mikesell (1962) and taking on board the integrative and holistic scope of

\footnotetext{
\# Alterra, Wageningen UR, P.O. Box 47, 6700 AA Wageningen, The Netherlands. E-mail: dirk.wascher@wur.nl
} 
Naveh and Lieberman (1994), the above definition reflects the terminology of recent methodologies in support of environmental reporting, such as the Driving Force Pressure - State Impact - Response framework (Figure 1), developed by the OECD (1997) and the EEA (1998). Conceptually rooted in ecosystem research, these frameworks suggest that ecological and socio-economic issues are engaged in causeeffect relations comparable to ecosystem processes such as between soil types, water quality and biological diversity.

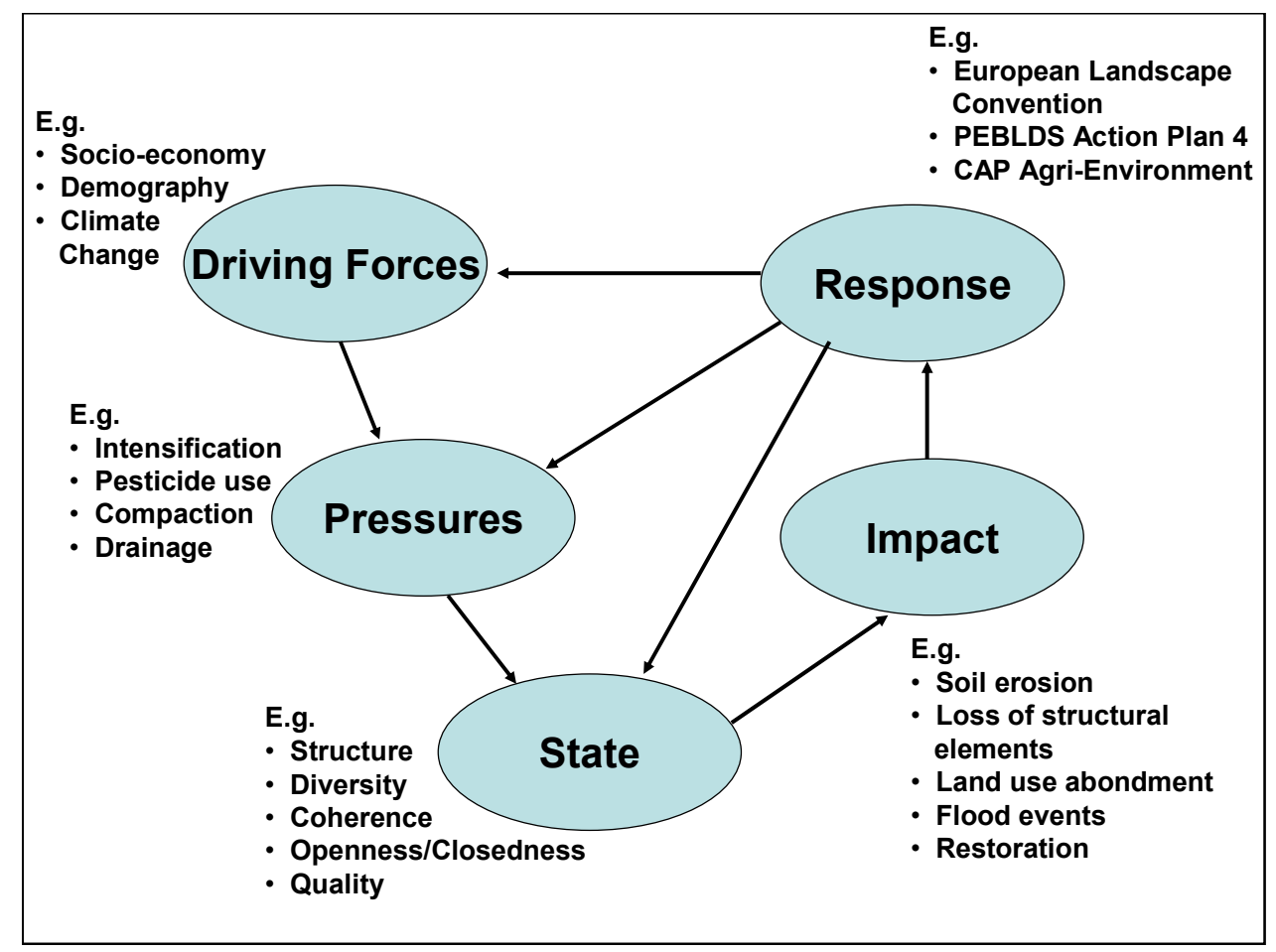

Figure 1. DPSIR Framework for landscape assessment

The degree to which human activities and natural processes are interacting or have been interacting in the past determines the character of a landscape. Landscape character can hence be considered to be the land's principle physiognomic profile in terms of climate, geomorphology, topography, soils and the associated natural vegetation and land use. Although the character of a landscape can be the object of human perception and evaluation, character is not to be confused with the quality of a landscape, which is mainly dependent on the functions that have been assigned to it, e.g. aesthetic, recreational, economic and ecological.

Obtaining a record of the landscape character should hence be considered the necessary prerequisite for identifying state or quality indicators for landscapes, and for identifying the most relevant pressure indicators that affect this state. Since ecological processes are spatial and functional components of natural as well as of cultural landscapes - only at different levels of scale - landscapes and ecosystems are not two complementary or separate systems, but form synthetic entities. This is echoed by Ellis et al. (2000), whose hierarchical landscape classification system builds upon ecotopes, which are defined as "the smallest homogeneous ecosystem units within landscapes".

Obtaining a record of the landscape character should hence be considered the necessary prerequisite for measuring the state or quality of a landscape, and for identifying the most relevant pressures that affect this state (Figure 2). 


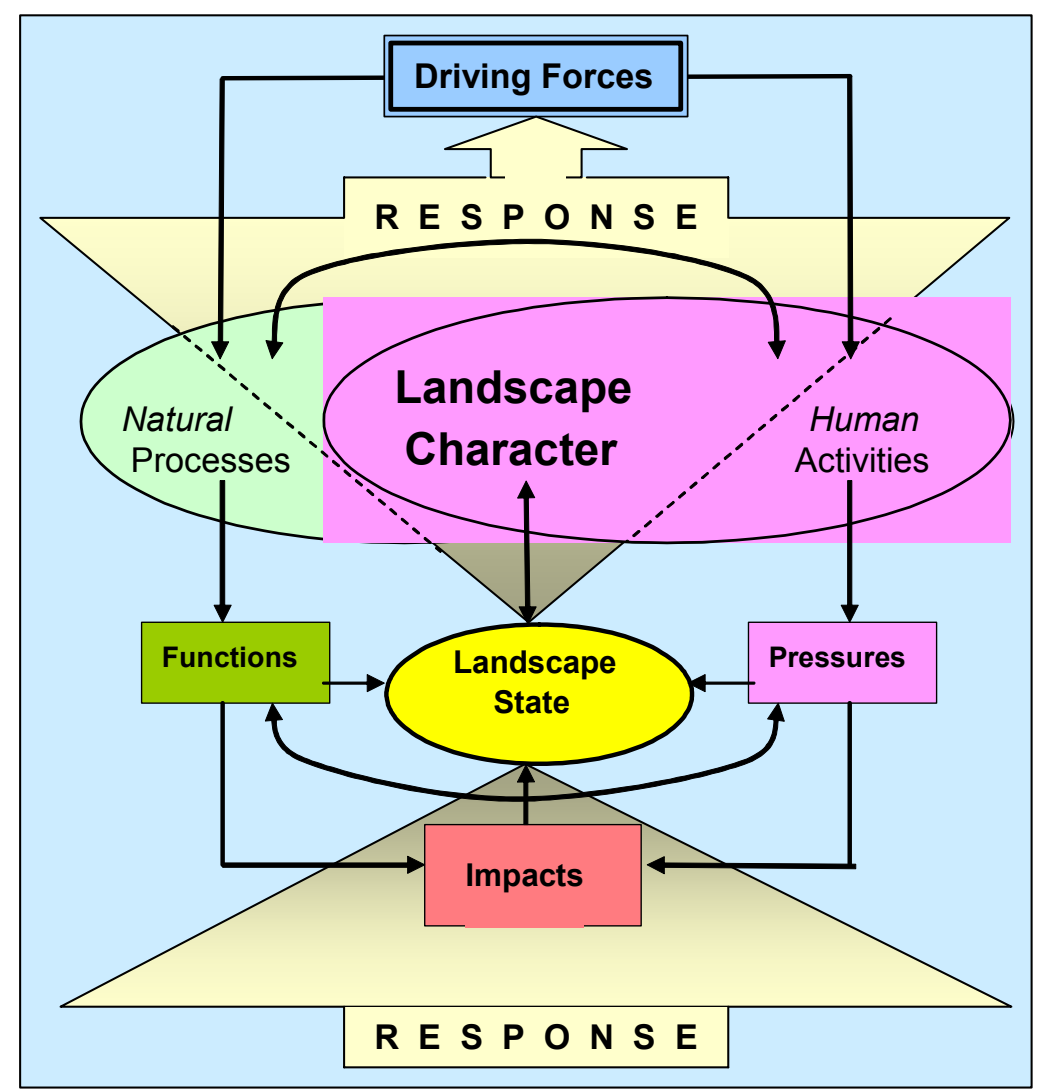

Figure 2. Revised DPSIR framework for landscapes

\section{Landscape-indicator review}

The analysis and valuation of complex systems like landscapes demand a research design of great variety. In a first step a selection of parameters to represent the whole system has to be carried out. These parameters indicate the present situation of landscapes and are as well used in data sets to define sustainable land-use systems. Furthermore, they serve in this nexus for the assessment of effects of a changing agricultural policy. Linked up to their application these parameters offer to be defined as landscape indicators.

Mainly driven by the critical debate about and the strategic perspectives for the future of Europe's Common Agricultural Policy (CAP) in the light of the WTO negotiations, environmental-quality concerns and the EU Accession process, the development of landscape indicators at the European level has entered both the policy and the research world.

The fact that the current international debate on landscape indicators is strongly 'driven' by the agro-environmental policy angle has quite naturally led to a somewhat biased selection. Table 1 presents landscape indicators that have been identified for three different purposes:

- Technical Report on European Landscapes (Wascher and Jongman in press)

- EU Concerted Action project on agro-environmental indicators (Wascher 2000)

- Draft Summary Report of the NIJOS/OECD Expert Meeting in Oslo 2002.

Although a certain difference in the approach can be expected between the more generic EEA Report and the two agro-environmental landscape-indicator concepts, a number of similarities between these indicator sets can be recognized. The reason for these similarities is mainly expressed in the categories or headings that provide the 
overall structure. The selection of the indicators themselves - in the cases where this has been done - is likely to be linked more strongly to data availability and scale.

Table 1. Landscape-state indicators identified through international approaches

\begin{tabular}{|c|c|c|}
\hline$E E A$ & $E L I S A$ & $O E C D$ \\
\hline 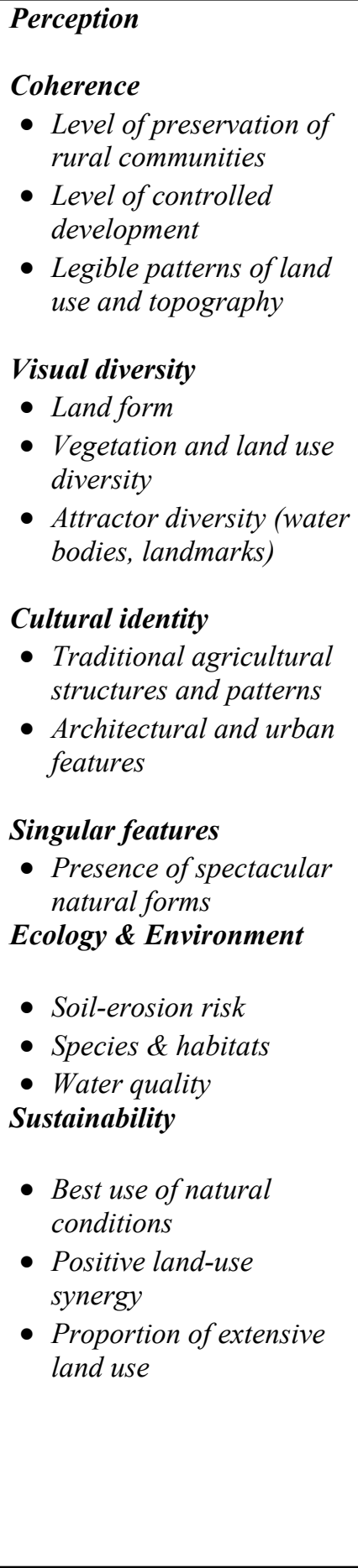 & $\begin{array}{l}\text { Perception \& Culture } \\
\text { - Openness versus } \\
\text { closedness } \\
\text { - Land recognized for its } \\
\text { scenic value } \\
\text { - Presence of key cultural } \\
\text { values }\end{array}$ & $\begin{array}{l}\text { Value } \\
\text { - Quality of life } \\
\text { - Sustainability } \\
\text { Function } \\
\text { - Recreation } \\
\text { - Cultural identity } \\
\text { tranquillity }\end{array}$ \\
\hline
\end{tabular}

The following two definitions of indicators might guide the analysis: "An indicator is a means devised to reduce a large quantity of data down to its simplest form retaining essential meaning for the questions that are being asked of the data" (Ott 
1978) and: "The indicators show changes over time for each criterion and demonstrate the progress made towards its specified objective" (MCPFE 1998).

Since the indicators presented in Table 1 reflect constraints deriving from project histories marked by strongly policy- and data-driven dynamics, this paper takes the opportunity to step back and to analyse their strengths and weaknesses on the background of broader scientific and societal requirements. For this purpose, the above indicators and their underlying concepts shall briefly be reviewed in more detail. A closer look at Table 1 shows that some of the conceptual premises are frequently conflicting with each other and that some indicator requirements are only partially fulfilled:

1. Methodological and conceptual linkages between the proposed indicators, the category under which they are listed and the related public or policy concern are ambiguous. For example, in the EEA approach, 'species and habitat diversity' are presented under the category 'Ecology \& Environment', while 'land form, vegetation and land-use diversity' are addressed as attributes of 'Perception'. Linked with each other and based on similar data sets these diversity indicators appear difficult to interpret in the context of environmental functions, human preferences and policy objectives.

2. The degree to which the proposed indicators reduce conceptual complexity while meeting policy targets differs strongly from case to case. So is the "proportion of extensively used land' considered an indicator for sustainability, 'heterogeneity/homogeneity' is considered a way of assessing the quality of a landscape's physical structure or 'quality of life' for measuring landscape value with regard to policy objectives (Dramstad and Sogge 2003). Their derivations must be regarded in themselves as rather complex exercises. Though statistical and spatial data are likely to exist (for certain countries) their relevance with regard to items such as coherence, sustainability or value is rather unclear and would in addition require adequate reference systems for interpreting such data.

3. The way indicators are measured and interpreted in the regional context by means of spatial integration remains unclear. Most indicators and the underlying concepts such as 'openness/closedness' (OECD), or 'legible patterns of land use and topography' for measuring 'coherence' (EEA) or 'biophysical adequateness of land use' (ELISA) require agreed-upon spatial reference systems that are meaningful at various levels (regional/national/European).

4. The combination of top-down approaches based on existing European data and bottom-up methodologies with national and regional input is in need of more specifications. Especially the assessment of perception issues such as cultural identity, presence of spectacular natural forms, attractor diversity or scenic value will require methodological approaches that are firmly rooted in bottom-up approaches and where linkages with top-down interpretations are developed in cooperation with stakeholders and policymakers.

This brief review illustrates that there are many commonalities between the different international approaches, but also various conceptual issues and operational gaps with regard to the practical implementation. An obvious dilemma appears to be the type of uncertainty with regard to the role of the main headings. Since transparency and consistency in this matter must be considered crucial for arriving at a valid indicator system, it is proposed to apply a rigid definition of terms and their methodological relations. The way of doing this is to differentiate between targets, vectors and measurable attributes. Without a clear agreement on how to use these terms, any approach is likely to lead to misinterpretations and confusion. 
Table 2 presents a system that links three main targets to three main criteria on a one-to-one basis, suggesting three relational pairs for which indicators should be developed. The functional relations between the three pairs are also recognized. The underlying assumptions that have led to this concept will be briefly explained.

Table 2. Key conceptual relations between targets and vectors for the selection of landscape indicators (Polman, Wascher and Rheenen in press)

\begin{tabular}{|c|c|c|c|}
\hline TARGETS & VECTORS & & \\
\hline & Structure & Management & Function \\
\hline Identity & $\begin{array}{l}\text { - Typology } \\
\text { - Diversity/coherence } \\
\text { - Naturalness } \\
\text { - Man-made objects } \\
\text { - Patterns, lines, points }\end{array}$ & & \\
\hline Sustainability & & $\begin{array}{l}\text { - Maintenance } \\
\text { - Mitigation } \\
\text { - Change (e.g. land use) } \\
\text { - Development } \\
\text { - Protection \& education }\end{array}$ & \\
\hline Value & & & $\begin{array}{l}\text { - } \text { Quality of life } \\
\text { - Cultural identification } \\
\text { - Productivity } \\
\text { - Biodiversity } \\
\text { - Environmental processes }\end{array}$ \\
\hline
\end{tabular}

\section{Identity x Structure}

The first target is strongly linked to structural appearance, representing above all a process of visual perception of a certain landscape condition. Although management activities could be part of the perception (e.g. farmers harvesting crop or cutting willows), the most persistent and dominant aspect is the result of the management, namely the image of the landscape, seen either with the eyes of the local observer or through the photos and digital snapshots from aerial photography and remote sensing. In this context, 'Identity' shall be defined as the possibility to recognize a specific type of landscape in contrast to another (adjacent) one and to do so by interpreting a set of structural components. The reason for defining the first target as 'Identity' instead of 'Cultural identity' (a possible choice) is the narrow connotation of 'cultural' in the context of structural attributes: although cultural identity may be hinged to a great deal on the visual appearance of a landscape, so may other forms of perceptions, e.g. purely aesthetic views or the scientific analysis of a landscape's physiognomic structure. This is why 'cultural identification' is considered to be a value attribute and hence a choice rather than a target in its own right. The attributes that describe structural aspects of landscapes are typology, diversity/coherence, naturalness, man-made objects (architecture, stone walls, etc.) as well as patterns, lines and points. 
Table 3. Targets, vectors and issues for developing landscape indicators

\begin{tabular}{|c|c|c|c|}
\hline Targets & Vectors & Issues & Indicators \\
\hline & Structure & $>$ Soil, land form \& wate & Soil type \\
\hline & & $>$ Natural coherence & Corridors \\
\hline & & $>$ Diversity & Landscape units \\
\hline & & $\begin{array}{l}\text { Scale/spatial } \\
\text { dimension }\end{array}$ & Size \\
\hline & & $>$ Openness/ & Urban forest \% \\
\hline & & closedness & Hemerobic class \\
\hline & & $>$ Naturalness & Shannon index \\
\hline & & $>$ Diversity & \\
\hline & & $>$ Key cultural features & Number/length \\
\hline & & $>$ Archeology & Number of sites \\
\hline & & $>$ Settlement pattern & Share of types \\
\hline Sustain- & Manaqement & $>$ Erosion protection & Soil / land use \\
\hline & & & Water retention \\
\hline & & $>$ Global impact & Ecol. footprint \\
\hline & & $>$ Pedological & Soil erosion \\
\hline & & $>$ Hydrological & Water quality \\
\hline & & $>$ Bio-climatic & Air quality \\
\hline & & $>$ Connectivity & Fragmentation \\
\hline & & $>$ Biodiversity & Species \\
\hline & & $>$ Habitats & \\
\hline Value & Function & $>$ Agriculture/forestry & $€ /$ hectare.year \\
\hline & & $>$ Tourism/recreation & $€$ revenues/year \\
\hline & & $>$ Business & Employment rate \\
\hline & & Green infrastructure & Bicycle km/unit \\
\hline & & $>$ Recreation & Facilities/unit \\
\hline & & $>$ Education & Museums/unit \\
\hline & & $>$ Landscape protection & Area coverage \\
\hline & & $>$ Supportcommittment & Budget, manage. \\
\hline & & $>$ Accessibility & Education \\
\hline
\end{tabular}

\section{Sustainability x Management}

The second target is considered to be closely linked to land use and hence to management. The assumption is that sustainability is entirely dependent on the way we manage the land. Management produces a great deal of the structural qualities as well as the values and therefore takes a central position in the proposed system. Management is in fact the means to realize all three targets - but it is not a target in itself. By linking sustainability to management - hence to this part of the concept that is most dominantly driven by human interference with the landscape - sustainability takes a superior role over both identity and values. The underlying assumption is that the targets of identity and value need to be rooted in sustainable principles in order to provide long-term perspectives for future generations. This implication is that we should not impose certain structural qualities or advocate values that are in conflict with sustainability principles. The attributes associated with sustainability and 
management are maintenance, mitigation, change (e.g. land use), development as well as protection and education. Through all these activities, human society is evoking a certain type of change - either of the landscape itself or in the people's relation to it.

\section{Value $x$ Function}

The last target addresses landscape functions as delivering socio-economic and environmental goods. Most conceptual frameworks link function and value as interdependent entities into an equation. The example of the self-regeneration processes associated with certain wetlands (e.g. estuaries or fens with extensive coverage of Phragmatis communis habitats) might illustrate this concept: the biochemical processes linking soils, hydrology and vegetation provide a(n ecosystem) function of regenerating clean water which is of high societal value. Ultimately, biodiversity is also a societal good, depending on the wide management of natural resources. Even if humans minimize their interference with a natural system it is ultimately a decision based on societal values.

The conceptual approach presented in Table 2 can form the basis for identifying key landscape issues and their associated landscape indicators. Table 3 illustrates possible perspectives for such an approach. In order really to identify adequate issues and indicators, the operational framework should be developed first. As mentioned earlier, all three targets and their associated vectors are interdependent. This is one of the reasons that there is a need to define interrelations further within an operational framework.

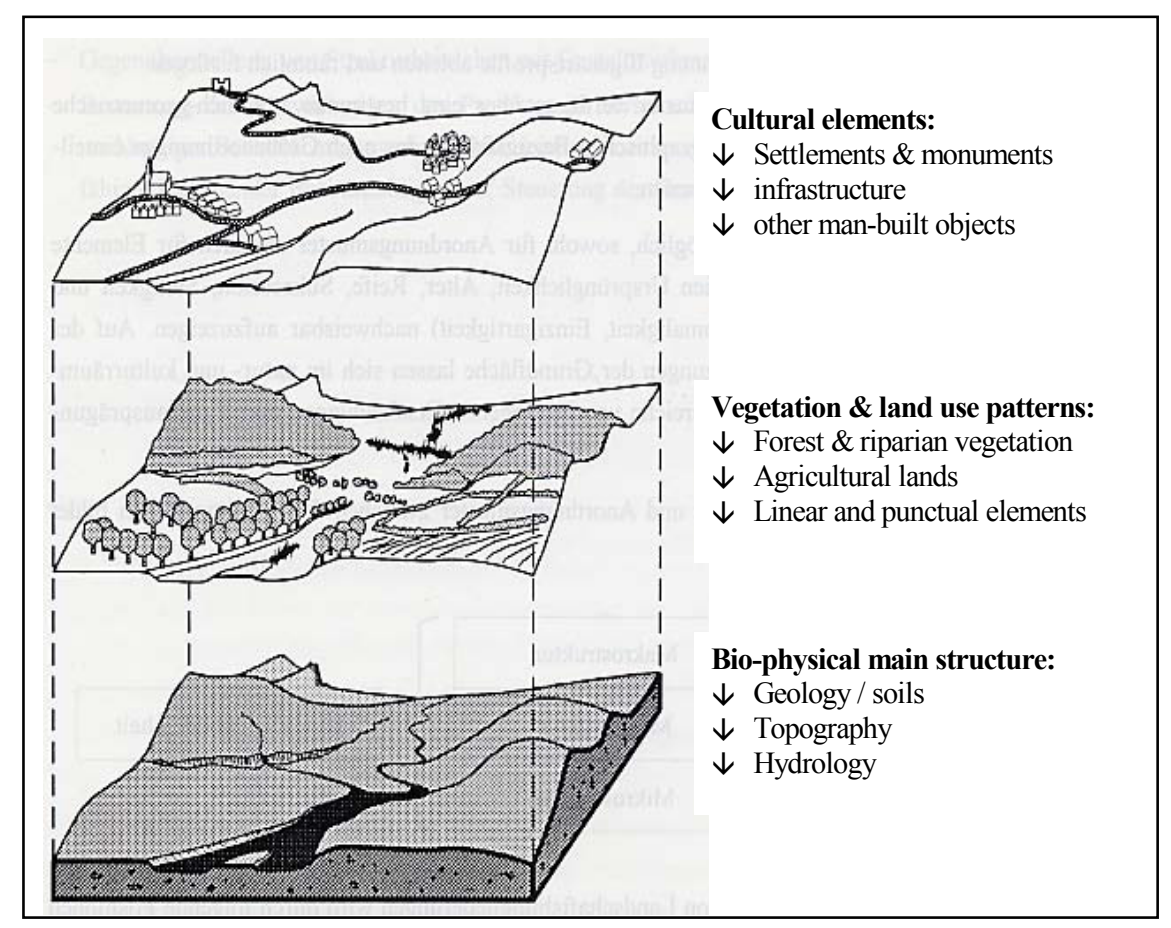

Figure 3. Landscape character consisting of three main layers: biophysical main structure, vegetation and land-use patterns and cultural elements (Wascher and Jongman in press; after Krause and Klöppel 1996) 


\section{Landscape-character assessment}

As complex socio-economic ecosystems with regionally distinct configurations of geomorphology, soil, water, vegetation and human land use, landscapes are the products of both human activities and natural processes that are following the vectors of driving forces such as policies, demography, economy or climate change. The degree to which human activities and natural processes are interacting or have been interacting in the past determines the character of a landscape (Figure 3). Landscape character can hence be considered the land's principle physiognomic profile in terms of climate, geomorphology, topography, soils and the associated natural vegetation and land use. Though the character of a landscape can be the object of human perception and evaluation, character is not to be confused with the quality of a landscape, which is mainly dependent on the functions that have been assigned to it, e.g. aesthetic, recreational, economic and ecological.

Directly in line with Von Humboldt (1867), who explained landscapes as 'dynamic systems of spatial structures' or with Rosenkranz (1850), who interpreted landscapes as 'units of stepwise-integrated local systems', modern landscape-character assessment introduces a hierarchy of spatial-structural levels in which higher units are composed of different subunits. Most recent definitions are as such: Landscape Character is " a distinct, recognisable and consistent pattern of elements in the landscape that makes one landscape different from another, rather than better or worse" (Countryside Agency 2002). Landscape quality (or state) is directly related to environmental, social or economic functions and values in terms of use, consumption and support services.

Obtaining a record of the landscape character should hence be considered a way of identifying the basic structures of their biophysical components and cultivation patterns. Understanding the structural character of a landscape is not only a prerequisite for measuring the state or quality of a landscape, but also for identifying the most relevant pressures that affect this state. Mainly in the United Kingdom, but also in Sweden, The Netherlands and Austria, different forms of Landscape Character Assessment are being implemented; some of them date back to the early 1970s. In England, for example, the Countryside Agency developed this technique as a tool to separate the classification and description of landscape character from landscape evaluation. The main objectives for such assessments are as follows:

- Identify what environmental and cultural features are present in a locality

- Monitor changes in the environment

- Understand a location's sensitivity to development and change

- Inform the conditions for any development and change.

\section{Landscape typologies}

The most striking aspect of the emerging Landscape Character Assessments implemented in England and Scotland is the role of the spatial units that are being identified and which are developed into landscape typologies that form a reference basis for future landscape evaluations. Landscape typologies or classifications are of significant importance for both character and state assessment, because:

- Landscape-character units provide the opportunity to identify policy issues at a region-specific and socially as well as economically relevant level 
- Landscape-character units provide a functional and methodological link between the biophysical main structure and the (agri)cultural and social-economic 'expression' of a landscape

- The use of the Geographic Information System in connection with statistical information stored in relational databases allows spatial-analytical assessments

- The development of different hierarchical layers that discern various landscape issues allows linking up with both administrative and environmental typologies

- Landscape-character areas provide practical tools for communicating landscape issues to stakeholders and policymakers

- They link fine-scale assessment to coarse-scale (top-down) assessments.

This is the reason that many OECD countries have - independently of landscapecharacter assessments - developed agricultural landscape classifications that serve as a reference basis for indicator assessments.

In the light of increasing policy demands at the international and national level, landscape-classification projects have been launched at the request of national and international agencies. While earlier attempts have been driven mainly by scientific interest of historical geographers, landscape ecologists or regional planners, recent initiatives are much more integrated in wider national monitoring frameworks and are targeting at concrete policy implementation in the field of sustainability, naturalresource management and environmental assessments. Table 4 provides an overview of selected classifications. More initiatives are known to exist, such as in Portugal, Spain, Poland and the Slovak Republic; however, detailed information was not available.

Table 4. Selected classifications in use for landscape-indicator assessments

\begin{tabular}{|lll|}
\hline Country & Classifications & Attributes \\
\hline England & Map of Landscape Character Areas & 111 Character Areas, \\
& & 587 Countryside Character Types $\left(1 \mathrm{~km}^{2}\right)$ \\
& Land Description Units (LDUs) & 7 Midland counties \\
Scotland & Natural Heritage Futures & 21 Areas \\
Netherlands & Landscape Types & 9 Main types, 21 subtypes \\
Norway & Agricultural Landscape Regions & 11 Main, 45 regions, 444 subunits \\
Sweden & Cultural Landscapes & $\left(1 \mathrm{~km}^{2}\right)$ \\
Hungary & Taxonomic distribution of Natural & 6 Macro-regions, 35 meso-regions, 75 \\
& Landscape Units & micro-regions and over 200 subgroups \\
Germany & Spatial structure of Cultural & 77 Units \\
& Landscapes & 30 Main types, 850 sub-units $\left(1 \mathrm{~km}^{2}\right)$ \\
& German Landscape Types & \\
Austria & Map of Austrian Cultural Landscapes & 12 Main / 37 sub-types $\left(1 \mathrm{~km}^{2}\right)$ \\
& (SINUS) \\
\hline
\end{tabular}




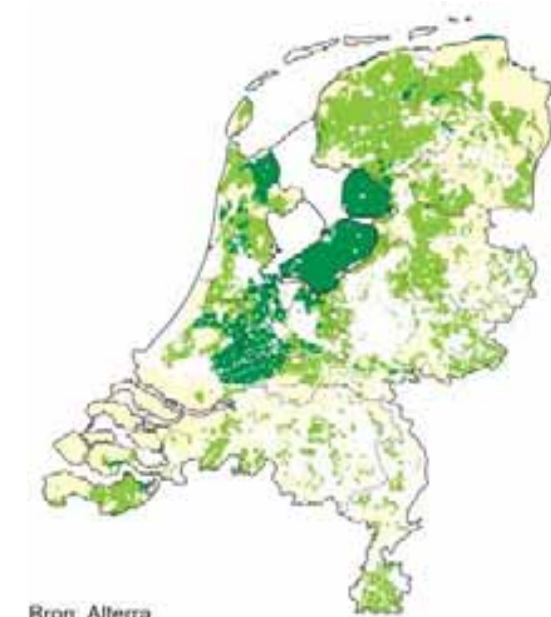

Bron. Alterra

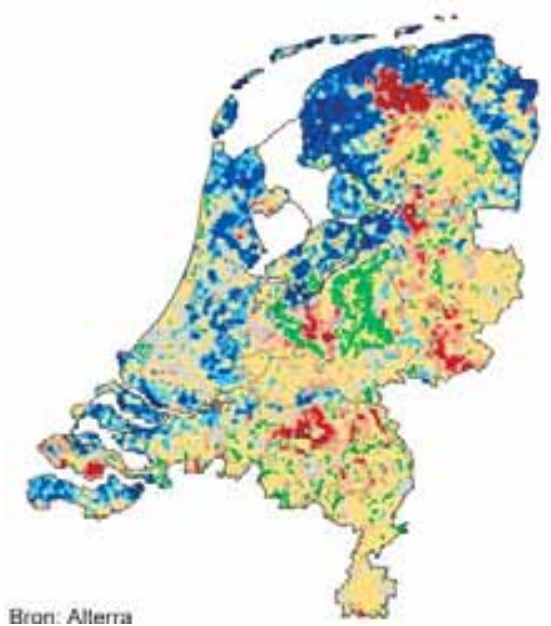

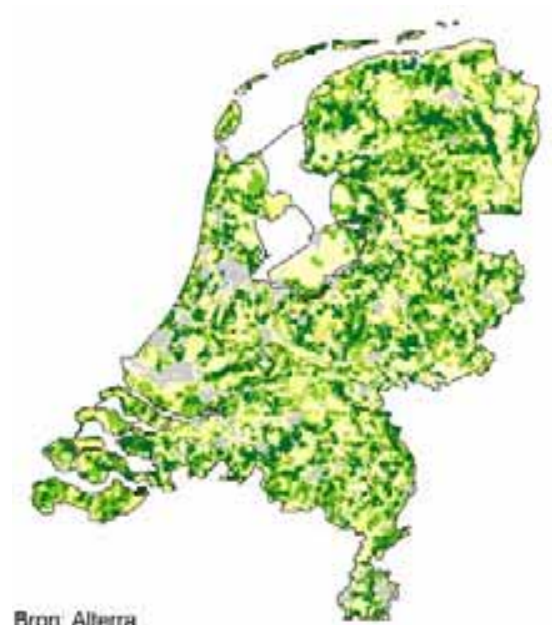

Bron. Alterra

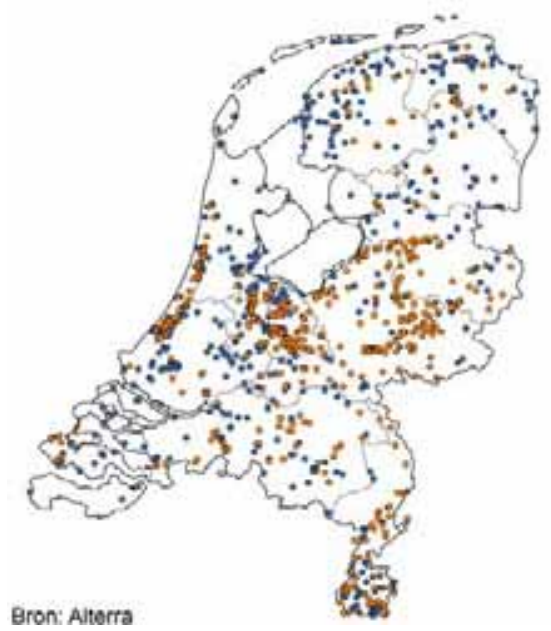

Figure 4. Landscape assessment: (a) visibility of cultivation process (light yellow: little, light green: good, dark green: very good, white: no data); (b) presence of structural components (light yellow: little, yellow: modest, light green: many, dark green: very many); (c) scale dimensions (grey: closed/urban, green: very closed/forest, pink: modestly small-scale landscape, red: small-scale landscape, dark-red: extreme small-scale landscapes, light blue: modestly open landscape, dark blue: open landscape, darkest blue: extremely open landscape, yellow: criteria do not apply); and (d) architectural historic sites: brown sites: estates and open space locations, blue sites: protected city and village ensembles (Farjon et al. 2000)

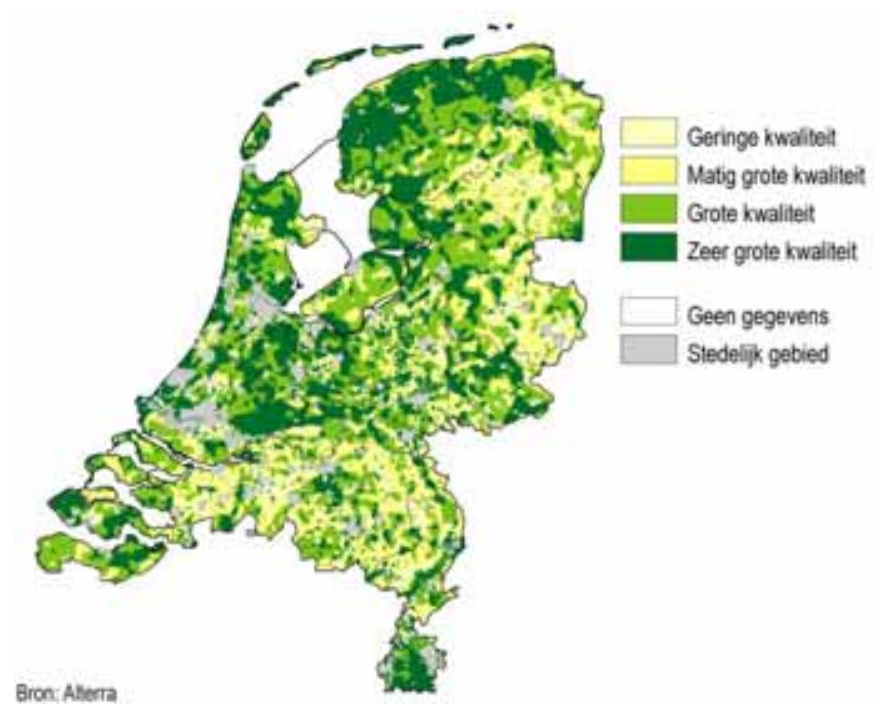

Figure 5. Rating of National Landscape Character as an indicator for landscape quality (geringe kwaliteit $=$ low quality, matig $\mathrm{k} .=$ moderate q., grote $\mathrm{k} .=$ high q., zeer grote k. = very high q.; geen gegevens $=$ no data, stedelijk gebied $=$ urban area) 


\section{Landscape assessment in The Netherlands}

In The Netherlands relatively long experience exists in landscape assessment on the basis of physical criteria that determine landscape character. One approach among a wide range of recent activities has been the 'National Character Rating' project, implemented by the Natuurplanbureau (Farjon et al. 2001; 2000). The objective of this project was to develop a map with high landscape values, hence a product that is targeting at landscape quality. Nevertheless, the exercise involved a number of steps that can be considered phases in a landscape-character assessment.

The assessment methodology follows a combination of the following issues:

- relief structure

- archaeological sites

- cultivation history

- architectural history

- scale dimension.

According to the conceptual framework presented in the previous chapter, the presence or absence of these issues (see Figure 4) is not necessarily an indicator for higher or lower landscape quality.

Figure 5 shows that the landscape-character aspects have actually been used to arrive at a landscape-quality assessment. The resulting integrated map has been developed on the basis of scores in two top classes for each criterion. The total score has been distributed into four even classes of surface coverage (from high to low quality).

According to the conceptual understanding of a landscape-character assessment as described in this paper, the interpretation of descriptive issues such as architectural and archaeological sites, even of scale and cultivation history is difficult to do in the context of quality judgment. If there would be trend data on the loss, degeneration or destruction of architectural or archaeological sites or if there would be an objective reference for judging the role of cultivation history and scale on the basis of their policy relevance for a given landscape type, the proposed rating could be considered a transparent quality assessment.

\section{Landscape assessment in the United Kingdom}

In 1993, English Heritage joined the Countryside Agency (then the Countryside Commission) inter-agency team to advise on the historic aspects of the developing methodology for assessing the landscape character of England. The aim was to develop a national framework of geographical areas that described what the landscape was, how it had evolved and how to use this knowledge better to guide and inform its protection, conservation, enhancement and restoration (Somper 2003).

The methodology began with a systematic analysis of the landscape. A pilot exercise had shown that 12 aspects - related to physiographic, ecological and cultural categories - determine the English countryside as people recognize it. A national dataset for each of these 12 aspects was prepared for our inter-agency project. I will offer a few examples of these. The datasets relating to the 12 aspects individually give summary information for every kilometre square in England. They were analysed using TWINSPAN (Hill 1979) and a geographic information system. This computerized process indicates areas with distinct combinations of characteristics. 

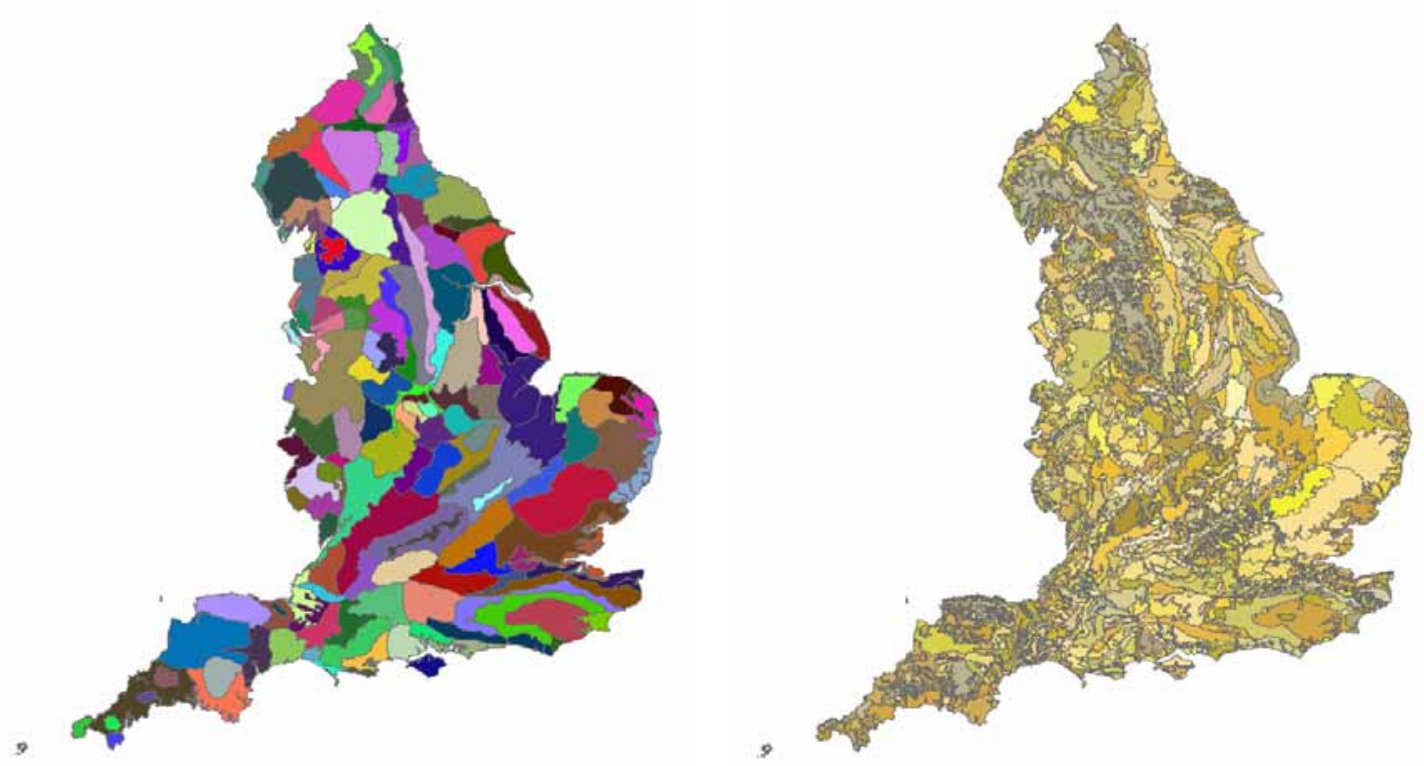

Figure 6. (left) Landscape Character Map of England (159 separate, distinctive character areas); (right) New landscape typology for England
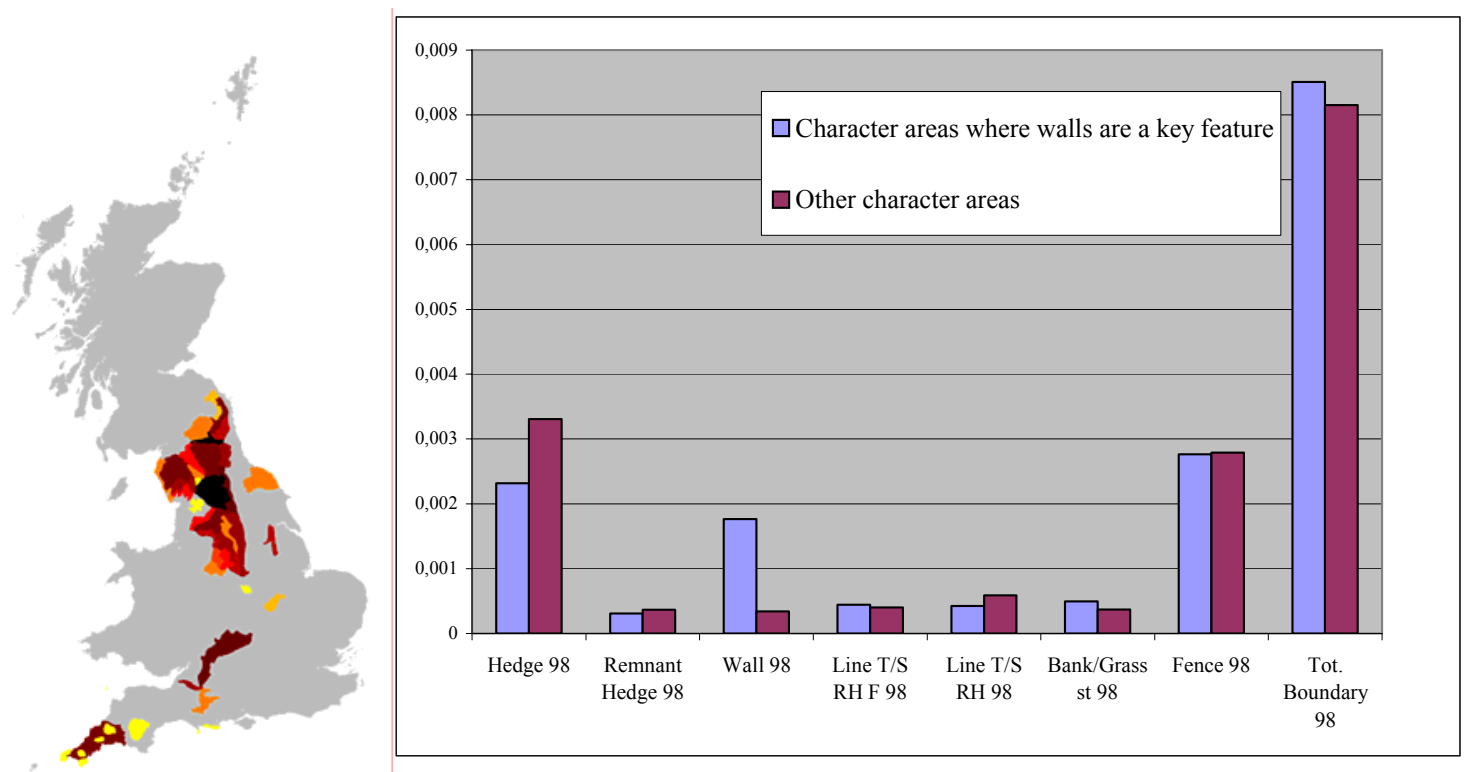

Figure 8. Example of landscape-quality assessment on the basis of Character Areas (Somper 2003)

Because classification of landscape is partly subjective, both the Agency and English Nature had also begun a parallel process of consultation, starting with our own staff and selected planning authorities. As the results of the computer analysis began to emerge, we broadened this perceptual exercise into a joint national consultation with a much wider range of partners. These included local authorities, regional government, nature-conservation and landscape organizations, landowners and farming organizations within each of our eight regions.

From this exercise, lasting almost a year, 'The Character of England, its Wildlife, Landscape and Natural Features' had been produced (Figure 6, left). While the three agencies have developed a single, joint map, it is being used in different ways. The 
Countryside Agency and English Heritage use the 159 landscape-character areas as their national strategic framework. Lately, combinations of physiology, land cover and cultural pattern have been used for mapping generic landscape-character types that fit within the 159 national Character Areas (Figure 6, right and Figure 7).

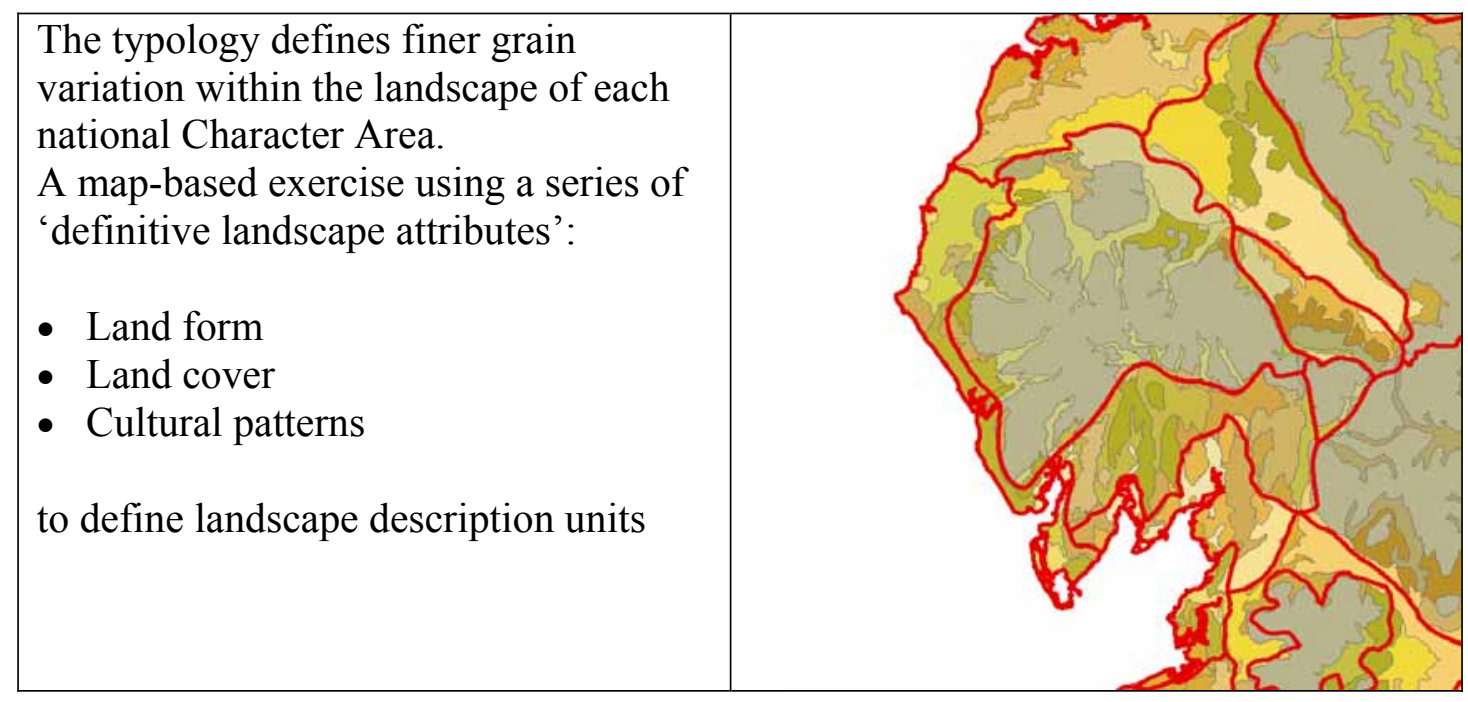

Figure 7. Example of creating the Landscape Character Typology: the Cumbria High Fells Character Area (Somper 2003)

The envisioned approach for developing landscape indicators is as follows:

- Focus for analysis and reporting should be at Character Area level

- National datasets are about the big forces for change, affecting all landscapes rather than picking up local-scale issues

- May need to group Character Areas to report some types of change

- Interpretation of the impacts of change depends on defining target/vision for each Character Area or group of Character Areas.

The example of England illustrates how landscape-character assessment can become instrumental in the development and interpretation of and reporting with indicators for landscape quality (Figure 8).

\section{Conclusions}

Many countries have taken a rather proactive approach towards the implementation of indicator-based landscape assessments. Over the last years, a series of countries have developed more refined methodologies in terms of spatial resolution and policy orientation, resulting in impressive monitoring and reporting products at the national level. Landscape-indicator fields on management and value are clearly less strongly developed. It can be assumed that a target approach towards the population of these indicator fields with existing data could provide a substantial advance in terms of cross-national comparisons. It requires a systematic approach when identifying the main types of management schemes and the accompanying financial structure.

Landscape structure is the indicator field that is most commonly in use and where an increasing number of techniques (e.g. Geographic Information Management) are being developed. The analysis of landscape structures is most consequently performed in countries that are undertaking 'Landscape Character Assessments' and where 
national landscape typologies as references for indicator assessments and interpretation are being developed. Landscape Character Assessments based on landscape typologies take a more region-specific approach than pure structureanalytical techniques.

National activities are increasingly supported by international projects such as the European Landscape Character Assessment Initiative (ELCAI, co-ordinated by Landscape Europe), the Environmental Risk Assessment for European Agriculture (ENRISK, co-ordinated by the European Centre for Nature Conservation), the Land Use and Land Cover Area Sampling (LUCAS, co-ordinated by the European Statistical Office) and the Millennium Assessment that includes a section on cultural landscapes.

As recommendations for the future can be summarized:

- Refine the conceptual framework and the identified indicators by developing consistent scales and references for gathering, analysing, presenting and interpreting data

- Support and take action to further the development and targeting of monitoring activities in the field of landscapes on the basis of the identified indicator core sets

- Support the development and application of national landscape typologies that can be linked to existing international classifications

- Establish a step-by-step procedure for initiating data-collection activities at the national level

- Establish a long-term monitoring and reporting system that links state, driving force, risk and response indicators into one integrated framework for sustainable agriculture.

\section{References}

Countryside Agency, 2002. Landscape character assessment: guidance for England and Scotland. Countryside Agency Publications, Cheltenham. [http://www.ccnetwork.org.uk/ca/LCA_Guidance.pdf]

Dramstad, W. and Sogge, C., 2003. Agricultural impacts on landscapes: proceedings from NIJOS/OECD expert meeting on agricultural landscape indicators in Oslo, Norway, October 7-9, 2002: developing indicators for policy analysis. Norwegian Institute for Land Inventory NIJOS, Oslo. NIJOS Report no. 07/2003.

[http://www.nijos.no/Publikasjoner/Rapporter/2003/oecd/kapitler.htm]

EEA, 1998. Europe's environment: the second assessment. European Environment Agency EEA, Copenhagen.

Ellis, E.C., Li, R.G., Yang, L.Z., et al., 2000. Long-term change in village-scale ecosystems in China using landscape and statistical methods. Ecological Applications, 10 (4), 1057-1073.

Farjon, J.M.J., Dijkstra, H., Dirkx, G.H.P., et al., 2001. Ontwerp voor indicator identiteit, monitoringsysteem kwaliteit groene ruimte (MKGR). Alterra, Research Instituut voor de Groene Ruimte, Wageningen. Alterra-Rapport no. 416. [http://www.alterra.nl/publ$\mathrm{prod} / \mathrm{rapporten/download/AlterraRapport416.pdf]}$

Farjon, J.M.J., Dirks, G.H.P., Koomen, A.J.M., et al., 2000. Neder-landschap Internationaal: Bouwstenen voor een selectie van gebieden landschapsbehoud. Alterra, Wageningen. Alterra-rapport no. 358. 
Hill, M.O., 1979. Twinspan: a Fortran program for arranging multivariate data in an ordered two-way table by classification of the individuals and attributes. Section of Ecology and Systematics, Cornell University, Ithaca, New York.

Krause, C.L. and Klöppel, D., 1996. Landschaftsbild in der Eingriffsregelung. Bundesamt für Naturschutz BfN, Bonn-Bad Godesberg. Angewandte Landschaftsökologie no. 8.

Landscape Europe, 2001. Summary report of an international workshop on European landscape mapping, August 8th 2001, Wageningen. Internal report, Alterra, Wageningen.

MCPFE, 1998. Ministerial Conference on the Protection of Forests in Europe: recognising the multiple roles of forests, Lisbon, June 1998. Ministerial Conference on the Protection of Forests in Europe MCPFE, Vienna.

Naveh, Z. and Lieberman, A.S., 1994. Landscape ecology: theory and application. 2nd edn. Springer, New York.

OECD, 1997. Environmental indicators for agriculture. Organisation for Economic Co-operation and Development OECD, Paris.

Ott, W.R., 1978. Environmental indices: theory and practice. Ann Arbor Science, Michigan.

Polman, N., Wascher, D.M. and Rheenen, T., in press. Multiple functions in the rural countryside: how can we know if they are sustainable? Project paper, Wageningen University, Wageningen.

Rosenkranz, K., 1850. System der Wissenschaft: ein philosophisches Encheiridion. Bornträger, Königsberg.

Somper, C., 2003. Countryside quality counts: tracking changes in England's landscape. In: Dramstad, W. and Sogge, C. eds. Agricultural impacts on landscapes: proceedings from NIJOS/OECD expert meeting on agricultural landscape indicators in Oslo, Norway October 7-9, 2002: developing indicators for policy analysis. Norwegian Institute for Land Inventory NIJOS, Oslo, 157-172. NIJOS Report no. 07/2003. [http://www.nijos.no/Publikasjoner/Rapporter/2003/oecd/12_Carol.pdf]

Von Humboldt, A., 1867. Ideen zu einem Geographie der Pflanzen nebst einem Naturgemälde der Tropenländer. F.G. Cotta, Tübingen.

Wagner, P.L. and Mikesell, M.W. (eds.), 1962. Readings in cultural geography. Univeristy of Chicago Press, Chicago.

Wascher, D.M. (ed.) 2000. Agri-environmental indicators for sustainable agriculture in Europe. European Centre for Nature Conservation ECNC, Tilburg. ECNC Technical Report Series.

Wascher, D.M. and Jongman, R.H.G. (eds.), in press. European landscapes: classification, evaluation and conservation. European Environment Agency, EEA, Copenhagen. EEA Environment Technical Reports. 